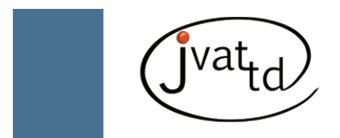

\title{
Wound infections secondary to snakebite in central Taiwan
}

\author{
Li-Wen Huang (1), Jiaan-Der Wang (2, 3), Jin-An Huang (1), Sung-Yuan Hu (4, 5), Lee-Min Wang (1, 6), \\ Yu-Tse Tsan $(4,5,7)$
}

(1) Department of Emergency Medicine, Taichung Veterans General Hospital, Taichung, Taiwan, Republic of China; (2) Division of Pediatric Emergency, Taichung Veterans General Hospital, Taichung, Taiwan, Republic of China; (3) Institute of Biochemistry and Biotechnology, Chung San Medical University, Taichung, Taiwan, Republic of China; (4) Division of Toxicology, Department of Emergency Medicine, Taichung Veterans General Hospital, Taichung, Taiwan, Republic of China; (5) School of Medicine, Chung Shan Medical University, Taichung, Taiwan, Republic of China; (6) Division of Emergency Medicine, National Yang-Ming University, Taipei, Taiwan, Republic of China; (7) Institute of Occupational Medicine and Industrial Hygiene, National Taiwan University College of Public Health, Taipei, Taiwan, Republic of China.

\begin{abstract}
There are very few microbiological data on wound infections following snakebites. The objective of this study was to investigate the treatment of secondary infection following snakebites in central Taiwan. Microbiological data and antibiotic sensitivity of wound cultures were retrospectively analyzed from December 2005 to October 2007 in a medical center in central Taiwan. A total of 121 snakebite patients participated in the study. Forty-nine (40.5\%) subjects were bitten by cobra (Naja atra); 34 of them had secondary infection, and 24 of them (70.6\%) needed surgical intervention. Cobra bites caused more severe bacterial infection than other snakebites. Morganella morganii was the most common pathogen, followed by Aeromonas hydrophila and Enterococcus. Gram-negative bacteria were susceptible to amikacin, trimethoprim/sulfamethoxazole, cefotaxime, cefepime, ciprofloxacin, and piperacillin/tazobactam. Enterococcus were susceptible to ampicillin, gentamicin, penicillin and vancomycin. It is reasonable to choose piperacillin/tazobactam, quinolone, second- or third-generation cephalosporin for empirical therapy following snakebite. Surgical intervention should be considered for invasive soft tissue infections.
\end{abstract}

Key words: snakebite, antivenom, venomous, cobra, bacterial infection, bacterial resistance, Taiwan.

\section{INTRODUCTION}

There are six main kinds of venomous snakes in Taiwan, including Naja atra (cobra), Bungarus multicinctus, Trimeresurus mucrosquamatus, Trimeresurus stejnegeri, Deinagkistrodon acutus, and Daboia russelii siamensis (1). Antivenom administration is the standard therapy for snakebite. Complications often occur following snakebite because of toxic hemorrhagic or neurotoxic effects with secondary bacterial infection. Exploring the bacteria responsible for the infections was the objective of this study. However, very few microbiological data on wound cultures following snakebites in Taiwan have been reported. There are challenges in predicting bacterial species and the sensitivity of antibiotics. In light of these considerations, medical records of snakebite patients in a 1300-bed teaching hospital in central Taiwan were retrospectively reviewed and analyzed from December 2005 to October 2007.

\section{MATERIALS AND METHODS}

Patient data including ID number, gender, age, exposure time; species of snakes; use of antibiotics; surgical intervention, and culture results were recorded. These cases represent snakebite occurrences in the central region of Taiwan. The identification of snake species was primarily based on the specimen brought to the hospital by the patient or the patient's family, or witnessed and identified by the patient. Secondary infection from snakebite was defined as progressive tissue necrosis or signs of wound infection including erythema, hotness, swelling, or pain which developed after adequate doses of 
antivenom, even if previous wound healing was observed. Wound cultures were performed if secondary infection was diagnosed, according to respective clinical conditions. Bacterial cultures were also collected during surgical intervention. No routine anaerobic culture was taken because of the low yield rate and less clinical significance. For better clinical decision making and outcome, microbiological data and antibiotic sensitivity of wound cultures were analyzed.

\section{RESULTS}

A total of 121 snakebite patients participated in the study (from December 2005 to October 2007). Seventy-four patients (61\%) were male. The patients aged from 4 to 90 years with an average age of 58 years. All 121 patients survived and were discharged after treatments. Forty-nine (40.5\%) patients were bitten by Naja atra (cobra), which is the most common type of venomous snakebite in central Taiwan.

Table 1. Snake species and secondary infection following snakebite in central Taiwan

\begin{tabular}{c|c|c|c|c}
\hline Types of snakes & $\begin{array}{c}\text { Number of } \\
\text { snakebite } \\
\text { patients }\end{array}$ & $\begin{array}{c}\text { Secondary } \\
\text { infection }\end{array}$ & $\begin{array}{c}\text { Surgical } \\
\text { intervention* }\end{array}$ & $\begin{array}{c}\text { Positive culture } \\
\text { results }\end{array}$ \\
\hline Naja atra & 49 & 22 & $20(83.3 \%)$ & 16 \\
\hline Trimeresurus mucrosquamatus & 19 & 4 & $2(8.3 \%)$ & 0 \\
\hline Trimeresurus stejnegeri & 19 & 4 & $2(8.3 \%)$ & 1 \\
\hline Bungarus multicinctus & 1 & 0 & 0 & 0 \\
\hline Others/unknown & 33 & 4 & 0 & 0 \\
\hline Total & 121 & 34 & 24 & 17 \\
\hline
\end{tabular}

*Surgical intervention in this table included simple bedside incision and debridement, debridement or fasciotomy in the operation room. All cases with positive culture results also received surgical intervention.

Table 2. Bacterial isolates identified in snakebite wounds

\begin{tabular}{c|c|c}
\hline Spp. of bacteria & $\begin{array}{c}\text { Number of patients with } \\
\text { positive culture }\end{array}$ & \begin{tabular}{c} 
Number of positive culture* \\
\hline Morganella morganii
\end{tabular} \\
\hline Aeromonas hydrophila & 4 & 15 \\
\hline Enterococcus & 4 & 2 \\
\hline Serratia marcescens & 2 & 2 \\
\hline Proteus vulgaris & 1 & 2 \\
\hline Staphylococcus aureus & 1 & 1 \\
\hline Bacteriodes fragilis & 1 & 1 \\
\hline Proteus mirabilis+ & 1 & 1 \\
\hline Pseudomonas aeruginosa & 1 & 1 \\
\hline Shewanela putrefaciens & 1 & 1 \\
\hline Acinetobacter baumannii & 1 & 1 \\
\hline Escherichia coli & 1 & 1 \\
\hline Yokenella regensburgei & 1 & 2 \\
\hline
\end{tabular}

*The same type of bacterial culture was found in different samples obtained from one patient. 
Table 3. Susceptibility of bacteria isolated from snakebite wounds to common antibiotics*

\begin{tabular}{|c|c|c|c|c|c|c|c|c|c|c|c|c|c|c|c|c|c|c|}
\hline $\begin{array}{l}\text { Spp. of } \\
\text { bacteria }\end{array}$ & $\frac{\text { 을 }}{\frac{1}{\alpha}}$ & Z & రి & $\stackrel{n}{<}$ & $\frac{\cup}{4}$ & Ł & Uै & 은 & $\stackrel{N}{0}$ & 은 & $\stackrel{0}{0}$ & ভั & हू & $\stackrel{n}{F}$ & $\frac{2}{\pi}$ & 은 & 壱 & பั \\
\hline $\begin{array}{c}\text { Morganella } \\
\text { morganii }\end{array}$ & $0 / 9$ & - & - & - & $1 / 9$ & $9 / 9$ & $0 / 9$ & $9 / 9$ & - & $9 / 9$ & $9 / 9$ & $9 / 9$ & $9 / 9$ & $9 / 9$ & - & $9 / 9$ & $2 / 2$ & $7 / 7$ \\
\hline $\begin{array}{l}\text { Aeromonas } \\
\text { hydrophila }\end{array}$ & $0 / 3$ & - & - & - & $0 / 3$ & $3 / 3$ & $0 / 3$ & $3 / 3$ & - & $2 / 3$ & $3 / 3$ & $3 / 3$ & $3 / 3$ & $3 / 3$ & - & $3 / 3$ & $1 / 2$ & $2 / 2$ \\
\hline Enterococcus & $3 / 3$ & $3 / 3$ & - & - & - & - & - & - & - & - & - & $3 / 3$ & - & - & $3 / 3$ & - & - & - \\
\hline $\begin{array}{c}\text { Serratia } \\
\text { marcescens }\end{array}$ & $0 / 2$ & - & - & - & $0 / 2$ & $2 / 2$ & $0 / 2$ & $2 / 2$ & - & $2 / 2$ & $2 / 2$ & $2 / 2$ & $2 / 2$ & $2 / 2$ & - & $2 / 2$ & - & $2 / 2$ \\
\hline Proteus vulgaris & $0 / 1$ & - & - & - & $0 / 1$ & $1 / 1$ & $0 / 1$ & $1 / 1$ & - & $1 / 1$ & $1 / 1$ & $1 / 1$ & $1 / 1$ & $1 / 1$ & - & $1 / 1$ & - & $1 / 1$ \\
\hline $\begin{array}{c}\text { Staphylococcus } \\
\text { aureus }\end{array}$ & - & $0 / 1$ & $0 / 1$ & $1 / 1$ & - & - & - & - & - & - & - & $1 / 1$ & - & $1 / 1$ & $1 / 1$ & $1 / 1$ & - & - \\
\hline $\begin{array}{l}\text { Bacteriodes } \\
\text { fragilis }\end{array}$ & - & $0 / 1$ & - & $0 / 1$ & - & - & - & - & - & - & - & - & - & - & - & - & - & - \\
\hline $\begin{array}{l}\text { Shewanela } \\
\text { putrefaciens }\end{array}$ & - & - & - & $1 / 1$ & - & $1 / 1$ & - & $1 / 1$ & $1 / 1$ & - & $1 / 1$ & $1 / 1$ & $1 / 1$ & $1 / 1$ & - & $1 / 1$ & - & $1 / 1$ \\
\hline $\begin{array}{c}\text { Acinetobacter } \\
\text { baumannii }\end{array}$ & - & - & - & $1 / 1$ & - & $0 / 1$ & - & - & $0 / 1$ & - & $0 / 1$ & $0 / 1$ & $0 / 1$ & $0 / 1$ & - & $0 / 1$ & - & $1 / 1$ \\
\hline Escherichia coli & $0 / 1$ & - & - & - & $0 / 1$ & $1 / 1$ & $0 / 1$ & $1 / 1$ & - & $0 / 1$ & $1 / 1$ & $0 / 1$ & $1 / 1$ & $1 / 1$ & - & $1 / 1$ & - & - \\
\hline $\begin{array}{l}\text { Yokenella } \\
\text { regensburgei }\end{array}$ & $0 / 1$ & - & - & - & $0 / 1$ & $1 / 1$ & $0 / 1$ & $1 / 1$ & - & $1 / 1$ & $1 / 1$ & $1 / 1$ & $1 / 1$ & $1 / 1$ & - & $1 / 1$ & $1 / 1$ & - \\
\hline
\end{tabular}

The same type of bacterial culture was found in different samples obtained from one patient, but it was defined as the same clone in the table. Amp: amipicillin, PCN: penicillin, Oxa; oxacillin, A/S: amipicillin/sulbactam, A/C: amoxicillin/clavulanic acid, P/T: piperacillin/tazobactam, Cef: cefazolin, Cefo: cefotaxime, CPZ: cefoperazone, Flo: flomoxef, Cefe: cefepime, Gen: gentamicin, Ami: amikacin, T/S: trimethoprim/sulfamethoxazole, Van: vancomycin, Cip: ciprofloxacin, Ert: ertapenem, Car: carbapenem.

${ }^{*}$ Number of patients with susceptibility to antibiotics/Number of patients with positive culture and antibiotic sensitivity test.

After antivenom therapy, 34 patients $(28.1 \%)$ had secondary infection and among them, 24 (70.6\%) patients needed surgical intervention (including wound incision, pus drainage, debridement, and fasciotomy for necrotizing fasciitis or compartment syndrome). The percentage of patients requiring surgery was $83.3 \%(20 / 24)$ for Naja atra, 8.3\% (2/24) for Trimeresurus mucrosquamatus, and 8.3\% (2/24) for Trimeresurus stejnegeri (Table 1). Wound cultures (including wound, pus, or tissue biopsy) were obtained from all patients who received surgical intervention.

A total of 17 patients had positive results for bacterial pathogen culture. Eight patients had culture results revealing more than two types of bacteria. Morganella morganii was the most common pathogen, followed by Aeromonas hydrophila and Enterococcus (Table 2). Among these 17 patients with microbiologically documented pathogens, 16 of them were bitten by cobra, and one by Trimeresurus stejneger. 
Seven patients who underwent surgical intervention had no grown bacterial culture. The average length of hospital stay for the 34 patients who had secondary wound infections, for 24 patients who needed surgical interventions, and for 17 patients with positive wound cultures was $12.4,17.4$ and 20.4 days, respectively.

Concerning antibiotic sensitivity tests, gramnegative bacteria were susceptible to amikacin, trimethoprim/sulfamethoxazole, cefotaxime, cefepime, ciprofloxacin, and piperacillin/ tazobactam. Isolated Enterococci were susceptible to ampicillin, gentamicin, penicillin, and vancomycin. One of the cultures had oxacillinresistant Staphylococcus aureus (Table 3).

\section{DISCUSSION}

T. mucrosquamatus is the most common type of venomous snake that attacks people in Taiwan (2-4). Bites by Deinagkistrodon acutus and Daboia russelii siamensis generally occur in the southern and eastern parts of the island, and cobra is the most common type in central Taiwan (3-5).

The origin of the bacteria in the mouth of the snakes is an important determinant for wound infection. Two of these are especially important, Morganella morganii and Aeromonas hydrophila. These bacteria were frequently isolated in snakebites, but they were not usually isolated from other soft tissue infections (2, 6-12). Some studies reported that severe soft tissue infections were caused by Aeromonas hydrophila or Vibrio vulnificus after snakebite $(8,11,13)$. These bacteria are not very common in the hospital environment. However, these species of bacteria are found in the mouth of snakes $(14,15)$. Aeromonas hydrophila was isolated in a snakebite infection in Sri Lanka (16). After that, other findings were reported in many countries $(8,10,11)$. In a prospective study, Morganella morganii was the most commonly isolated bacteria in adequately collected samples of abscesses caused by bite of Bothrops snakes in Brazil (9). Retrospective studies also reported this finding. Morganella morganii was also isolated from the mouth of healthy and freshly caught Bothrops jararaca (14).

According to our survey and previous reports, a cobra bite causes more severe bacterial infection than other kinds of snakebites (2). As a result, more severe complications, such as necrotizing fasciitis or compartment syndrome are observed, and therefore, more surgical interventions are required. The cobra venom causes extensive local tissue destruction, mainly because of the effect of cytotoxins and the myotoxic phospholipase $A_{2}$ (17). The larger number of oral bacterial colonization in cobras is one of the reasons for this result $(15,18)$. The oral cavity of cobras contains a wide range of pathogenic bacteria, including gram-negative bacterial species such as Morganella morganii, Aeromonas hydrophila and Proteus, and gram-positive bacteria including Enterococcus faecalis, coagulase-negative Streptococcus as well as anaerobic species $(15,18)$.

In our survey, most wound cultures were gram-negative bacillus. Only a few were gram-positive cocci such as Enterococcus and Staphylococcus aureus. Mixed bacterial infections were commonly observed in wound cultures with a combination of gram-positive, gram-negative, and anaerobic microorganisms. Morganella morganii and Enterococcus species were the most common pathogens. Other studies on snakebite and bacteriology in northern Taiwan reported similar culture results (2).

Early use of antivenom is the standard therapy for snakebite. Prophylactic use of antibiotics does not decrease the rate of secondary infection and is still controversial $(19,20)$. In our practice, the firstline empirical antibiotic therapy for snakebite is amoxicillin-clavulanate or amipicillin-sulbactam. However, most bacteria were resistant to these antibiotics according to the culture results. And if the wound was very severe, it would require surgical intervention.

As reported by previous surveys on snakebites, gram-negative bacteria associated with wound infection were sensitive to levofloxacin. Enterococcus faecalis and anaerobes were sensitive to amoxicillin/clavulanate. Therefore, the first line of empirical antibiotics includes amoxicillin/clavulanate plus levofloxacin (2, $5,15,18)$. According to our sensitivity tests, it is also reasonable to administer piperacillin/ tazobactam, quinolone, and second- or thirdgeneration cephalosporin for empirical therapy after snakebite, especially severe wound infections $(2,18)$. Amoxicillin-clavulanate or amipicillinsulbactam alone does not cover effectively. Surgical intervention should be considered for invasive soft tissue infections and necrosis.

It is hard to predict if a wound infection will follow after adequate antivenom therapy. Possible 
reasons for secondary wound infections would be insufficient use of antibiotics or ineffectiveness of antibiotics against highly invasive pathogens. Further surveys should be conducted to predict the risks of secondary wound infections and the effectiveness of prophylactic antibiotics.

\section{COPYRIGHT}

(c) CEVAP 2012

\section{SUBMISSION STATUS}

Received: February 8, 2012.

Accepted: May 28, 2012.

Abstract published online: June 4, 2012.

Full paper published online: August 31, 2012.

\section{CONFLICTS OF INTEREST}

The authors declare no conflicts of interest.

\section{CORRESPONDENCE TO}

Yu-Tse Tsan, Division of Toxicology, Department of Emergency Medicine, Taichung Veterans General Hospital, Taichung, Taiwan, Republic of China. Phone: 8864 23592525, ext. 3604. Fax: 88642374 1359. Email: janyuhjer@gmail.com.

\section{REFERENCES}

1. Chen YC, Chen MH, Wang LM, Wu JJ, Huang CI, Lee $\mathrm{CH}$, et al. Antivenom therapy for crotaline snakebites: has the poison control center provided effective guidelines? J Formos Med Assoc. 2007;106(12):105762.

2. Chen CM, Wu KG, Chen CJ, Wang CM. Bacterial infection in association with snakebite: A 10-year experience in a northern Taiwan medical center. J Microbiol Immunol Infect. 2011;44(6):456-60.

3. Chang KP, Lai CS, Lin SD. Management of poisonous snake bites in southern Taiwan. Kaohsiung J Med Sci. 2007;23(10):511-8.

4. Hung D. Taiwan's venomous snakebite: epidemiological, evolution and geographic differences. Trans R Soc Trop Med Hyg. 2004;98(2):96-101.

5. Chen JC, Liaw SJ, Bullard MJ, Chiu TF. Treatment of poisonous snakebites in northern Taiwan. J Formos Med Assoc. 2000;99(2):135-9.

6. Garg A, Sujatha S, Garg J, Acharya NS, Chandra Parija S. Wound infections secondary to snakebite. J Infect Dev Ctries. 2009;3(3):221-3.

7. Jorge MT, Ribeiro LA. Infections in the bite site after envenoming by snakes of the Bothrops genus. J Venom Anim Toxins. 1997;3(2):264-72.
8. Jorge MT, Nishioka S de A, de Oliveira RB, Ribeiro LA, Silveira PV. Aeromonas hydrophila soft-tissue infection as a complication of snake bite: report of three cases. Ann Trop Med Parasitol. 1998;92(2):213-7.

9. Jorge MT, Ribeiro LA, da Silva M, Kusano E, de Mendonça J. Microbiological studies of abscesses complicating Bothrops snakebite in humans: A prospective study. Toxicon. 1994;32(6):743-8.

10. Nishioka S de A, Silveira PV. A clinical and epidemiologic study of 292 cases of lance-headed viper bite in a Brazilian teaching hospital. Am J Trop Med Hyg. 1992;47(6):805-10.

11. Angel MF, Zhang F, Jones M, Henderson J, Chapman SW. Necrotizing fasciitis of the upper extremity resulting from a water moccasin bite. South Med J. 2002;95(9):1090-4.

12. May AK. Skin and soft tissue infections: the new surgical infection society guidelines. Surg Infect (Larchmt). 2011;12(3):179-84.

13. Wu CH, Hu WH, Hung DZ, Peng YC, Yang DY. Snakebite complicated with Vibrio vulnificus infection. Vet Hum Toxicol. 2001;43(5):283-5.

14. Jorge MT, de Mendonca JS, Ribeiro LA, da Silva ML, Kusano EJ, Cordeiro CL. Bacterial flora of the oral cavity, fangs and venom of Bothrops jararaca: possible source of infection at the site of bite. Rev Inst Med Trop São Paulo. 1990;32(1):6-10.

15. Shek KC, Tsui KL, Lam KK, Crow P, Ng KH, Ades G, et al. Oral bacterial flora of the Chinese cobra (Naja atra) and bamboo pit viper (Trimeresurus albolabris) in Hong Kong SAR, China. Hong Kong Med J. 2009;15(3):183-90.

16. Thisyakorn U, Thisyakorn C. Aeromonas infection following a snake bite: a case report. Southeast Asian J Trop Med Public Health. 1988;19(2):307-8.

17. Reali M, Serafim FG, da Cruz-Höfling MA, Fontana MD. Neurotoxic and myotoxic actions of Naja naja kaouthia venom on skeletal muscle in vitro. Toxicon. 2003;41(6):657-65.

18. Lam KK, Crow P, Ng KH, Shek KC, Fung HT, Ades G, et al. A cross-sectional survey of snake oral bacterial flora from Hong Kong, SAR, China. Emerg Med J. 2011;28(2):107-14.

19. Kularatne SA, Kumarasiri PV, Pushpakumara SK, Dissanayaka WP, Ariyasena H, Gawarammana IB, et al. Routine antibiotic therapy in the management of the local inflammatory swelling in venomous snakebites: results of a placebo-controlled study. Ceylon Med J. 2005;50(4):151-5.

20. Jorge MT, Malaque C, Ribeiro LA, Fan HW, Cardoso JL, Nishioka SA, et al. Failure of chloramphenicol prophylaxis to reduce the frequency of abscess formation as a complication of envenoming by Bothrops snakes in Brazil: a double-blind randomized controlled trial. Trans R Soc Trop Med Hyg. 2004;98(9):529-34. 